\title{
Comparative Analysis of Settlement and Pore Water Pressure of Road Embankment on Yan soft soil Treated with PVDs
}

\author{
Rufaizal Che Mamat ${ }^{\text {a b* }}$, Anuar Kasa ${ }^{c}$, Siti Fatin Mohd Razali ${ }^{\text {c }}$ \\ ${ }^{a}$ Ph.D. Candidate in Geotechnical Engineering, Centre for Engineering Education Research (PeKA) \& Smart and Sustainable \\ Township Research Centre (SUTRA), Faculty of Engineering \& Built Environment, Universiti Kebangsaan Malaysia, 43600, Bangi, \\ Selangor, Malaysia. \\ ${ }^{b}$ Senior Lecturer, Department of Civil Engineering, Politeknik Ungku Omar, 31400, Ipoh, Perak, Malaysia. \\ ${ }^{c}$ Senior Lecturer, Faculty of Engineering \& Built Environment, Universiti Kebangsaan Malaysia, 43600, Bangi, Selangor, Malaysia.
}

Received 09 March 2019; Accepted 20 June 2019

\begin{abstract}
The application of prefabricated vertical drains (PVDs) in the road embankment construction has been successfully performed in many projects throughout the country. The simulation of finite element method (FEM) can assist engineers in modelling very complex structures and foundations. This paper presents a plane-strain numerical analysis that was performed to verify the effectiveness of the model embankment stabilised with PVD using Plaxis 2D version 8 . This study employed the smear effect of permeability ratio $\left(k_{r}\right)$ of 3 in the PVD modelling. The data of settlement and pore water pressure in the left and right sides of road embankment were monitored for 177 days, then the data were collected and compared by a numerical simulation. The coefficient of determination $\left(R^{2}\right)$ was used to assess the performance of the comparative analysis. The results of numerical simulation on settlement and pore water pressure obtained a coefficient of determination of greater than 0.9 which has reached a good agreement with those of the field measurement. On other the hand, there was no significant difference in the performance between both sides of the embankment. The smear effect parameter $\left(k_{r}=3\right)$ is recommended for PVD designs and can provide accurate FEM prediction.
\end{abstract}

Keywords: Soft Soil; Prefabricated Vertical Drains; Smear Effect; Finite Element Method; Field Measurement.

\section{Introduction}

Road construction on soft soil is often become the main issue faced by engineers today. This is because soft soil has high moisture content, high compressibility, and low shear strength [1]. This has led to the failure of bearing capacity and the occurrence of excessive settlement. The construction of the embankment will create external loading to the soft ground. The additional burden imposed on the soft ground causes consolidation settlement over a considerable period of time. Thus, a primary concern of embankment construction on soft ground is the post-construction settlement. Various techniques can be used to solve this geotechnical problem. Over the last decade, many researchers have carried out studies on soft soil properties such as soil-cement columns [2], prefabricated vertical drains (PVDs) [3], concrete piles [4], and others. However, ground soft soil improved with PVDs approach is often used in Malaysia because this technique is easier to install and it is economical.

Consolidation of soft soils by PVDs is the most popular techniques because it accelerates consolidation and reduces

* Corresponding author: rufaizal.cm@gmail.com

http://dx.doi.org/10.28991/cej-2019-03091357

(C) 2019 by the authors. Licensee C.E.J, Tehran, Iran. This article is an open access article distributed under the terms and conditions of the Creative Commons Attribution (CC-BY) license (http://creativecommons.org/licenses/by/4.0/). 
the drainage path [5]. In addition to improving the slope safety factor, it also reduces the effects of excess pore pressure, minimizes the lateral deformation and bulk vertical hydraulic conductivity of the foundation [6]. Generally, PVDs consists of a hard drainage core that is covered by nonwoven geotextile as a filter. It is installed with a pushing a mandrel to the ground foundation until the desired depth. The effect of this installation will cause a significant disturbance of the clay layer surrounding the drain known as the smear zone. The smear effect for the consolidation rate of PVD with equivalent hydraulic conductivity should be considered. Numerical methods are often preferred to adopt by engineers in design phase because it can save the cost and time of the project compared with analytical methods. In addition to this, this method can assist engineers in modelling very complicated ground of foundation and structural elements.

In recent years, there has been increasing interest in numerical simulations of the embankment with PVDs. The significant aspect for embankment with PVDs design is smear effect. There are two parameters of smear effect, i.e., the zone diameter of the smear $\left(d_{s}\right)$ and the smear effect of permeability ratio $\left(k_{r}\right)$. Traditionally, the researchers determine the value of these parameters based on the literature as there is no comprehensive method to measure it so far [5, 7]. Previous studies have reported a range of the smear effect of permeability ratio selected values are from 1.3 to 10 . Recent evidence suggests that the smear effect of permeability ratio of 3 can produce a FEM prediction with high accuracy [8]. However, the lack of validation of this value has become a problem because the suitability employed to all cases as in Malaysia which has a climate that is different from other countries. Most studies in the field of numerical solution have only focused on behaviour performance $[9,10]$. This indicates that there is a need to perform a validation study for this parameter value.

The accuracy of FEM simulation results reflects the real condition of the site is very important in the design that later could match back the field monitoring results. Thus, this paper focuses on assessing the performance of FEM prediction with the the smear effect of permeability ratio of 3 . Hence, the main purpose of this study is to analyzse the comparison between the settlement and pore water pressure produced through FEM simulation and those of the field measurements. For this study, the equivalent horizontal permeability $\left(k_{h p l}\right)$ proposed by Hird [11] was employed in the FEM simulation. On the other hand, the road embankment was simulated numerically using a 2D model with plane strain conditions.

\section{Literature review}

Ground improvement techniques with PVDs were initially introduced by Kjellman [12] through cardboard wick drains. Subsequently, several case studies have reported the successful application of PVDs such as Ballina Bypass, Australia [13], Yaoqiang Airport runway, China [14], and Ramp ES, Ohio [15]. Numerous studies have explained the advantages of PVDs, such as an increase in soil strength [7] and reduce in the total settlement [16]. Furthermore, this technique is also able to improve the highway construction rate and give a good impact on the environment [17]. Due to its effectiveness in tackling the settlement problem, the installation of PVDs has become popular in the construction industry. It may shorten the drainage route by allowing the pore from the ground to flow horizontally into the drain. The water that meets along the drain will be released to the ground surface and then drained into the side drain. The permeability of the soil and a stream of water flowing to the ground surface is a key factor in delaying the consolidation process.

A considerable amount of literature on the research and development in soft ground improvement techniques with PVDs approaches has been published. The literature began in 1948, Barron [18] introduced a theory solution for soil consolidation. Several studies on PVDs such as the investigation of affecting factors behaviour [19], the analysis on the effect of vertical drains in plain strain condition [16], and the characterisation of a smear zone around vertical drains [20] have been reported. Smear effects are among the factors that affect the performance of embankment treated with PVD which reduces the lateral permeability of the ground [21]. Research on smear effects has become increasingly intense since it was introduced by Barron [18], who found the presence of smear zone greatly influenced horizontal consolidation. Some researchers who often highlight their research on the smear effects are Hansbo [22-24], Rixner [25], Onoue [26], Almeida and Ferreira [27], Hird [8,11,28], Indraratna and Redana [29], Chai and Miura [19], and Rujikiatkamjorn [30]. In the smear zone, soil permeability decreases due to groundwater flowing through the PVDs. Therefore, Hird [11] has introduced an equation to determine the permeability in the smear zone.

Among the parameters required to determine the permeability is the smear effect of permeability ratio. The value of the smear effect of permeability ratio is difficult to be determined as many uncertainties are involved [19,23,31]. In addition, the value of this parameter is also difficult and complicated to be determined by a laboratory method [5]. Most researchers estimate the value of this parameter based on the literature [5,7], but there are also those who used the method of trial and error and the results were not always consistent [23]. A number of studies reported that the value of the smear effect of permeability ratio is $3[8,18,24,26,27]$, and it was employed in numerical solutions and found that the FEM simulation results had relatively high accuracy. Moreover, climate factors can affect PVDs engineering characteristics and damage design targets [32]. Thus, the evidence presented in this section highlight the need to determine FEM's predictive performance with the smear effect parameters for cases in Malaysia. 


\section{Case Study and Work Programme}

The study was conducted based on the part of road construction projects in Yan, Kedah, Malaysia. Overall, this construction site is an agricultural area for paddy planting. Because this area consists of soft soil, engineers have proposed two techniques of soil improvement, i.e., piles and PVDs with surcharge. The PVDs were installed in 12 separate locations which include the total track length of about $5.5 \mathrm{~km}$. In this study, one of these locations was employed for a numerical simulation. Based on the site investigation conducted, the ground foundation consists of a thick 2-m thick clay silt and followed by $5 \mathrm{~m}$ of silty clay. The subsequent layer is $3 \mathrm{~m}$ of soft clay and $9 \mathrm{~m}$ of silty clay while the last layer is clayey silt with a thickness of about $18 \mathrm{~m}$. The position of the groundwater level is $2.3 \mathrm{~m}$ from the ground surface as shown in Figure 1.

The schematic diagram of research methodology is summarised in Figure 2. The scope of work includes field testing such as standard penetration test (SPT) and laboratory testing such as 1D consolidation test, unconsolidated undrained triaxial test (UU), particle sizes analysis, Atterberg test, and specific gravity test. The soil of foundation is classified according to the Unified Soil Classification System (USCS). The summary of soft ground properties in Yan is tabulated and presented in Table 1. Installation of field measurement instrument includes two settlement marker, i.e. rod settlement gauge (RSG) and pneumatic piezometers were installed on the left and right of the road embankment. These instruments installed are intended to investigate the behaviour of the embankment on the soft soils. The settlement plate of the left and right sides of embankment were installed at a depth of 4.6 and $4.2 \mathrm{~m}$ from the surface of the subsoil, respectively. In addition, pneumatic piezometers were installed at a depth of 5 and $12 \mathrm{~m}$ on the left and right of the embankment, respectively. Field measurement data were monitored and collected weekly for 177 days. Settlement and pore water pressure data observed were summarised and interpreted to the parameters required for the simulation in FEM analysis.

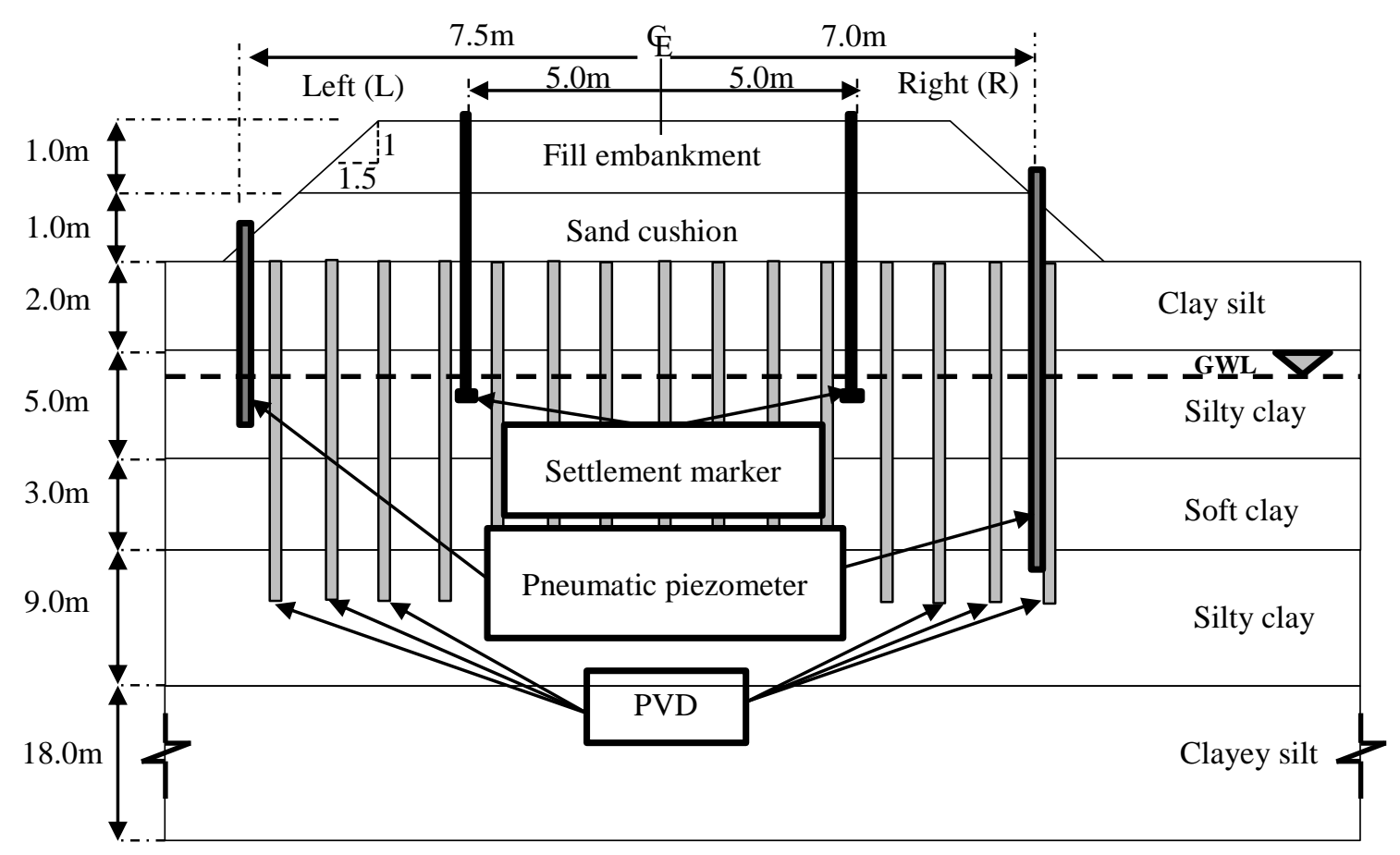

Figure 1. Cross section of an embankment with the subsoil profile and installation location instruments

Site work programs of this study include the construction of work platforms, embankments and installation of PVDs. The construction of the work platform comprises two layers of compacted sand and is known as a sand cushion. The first layer of the sand cushion was placed above the ground surface with a height of $0.7 \mathrm{~m}$ and compacted. After 14 days of short consolidation, the PVDs were installed into a $14-\mathrm{m}$ ground foundation with $1.5 \mathrm{~m} \mathrm{c} / \mathrm{c}$ spacing in a triangular pattern. The steel mandrel with a drain inside it moved up and down through the cylinder system and the win on excavators' hydraulic system was used for PVDs installation. Subsequently, another $0.3 \mathrm{~m}$ of the sand cushion was placed and compacted with compacting machines. This work platform is allowed for the 14-day consolidation process. Then, 1-m thick fill embankment placed on the work platforms was for 7 days and allowed the process of consolidation in 177 days for field measurement monitoring. The fill embankment was compacted built with the crest width, and the side slope is $11 \mathrm{~m}$ and $1 \mathrm{~V}: 1.5 \mathrm{H}$, respectively. 
Table 1. Yan's soft soil properties

\begin{tabular}{ccccccc}
\hline Soil strata & USCS & SPT N & $\boldsymbol{G}_{\boldsymbol{s}}$ & $\boldsymbol{C}_{\boldsymbol{c}}$ & $\boldsymbol{e}_{\boldsymbol{o}}$ & $\boldsymbol{k}(\mathbf{m} / \mathbf{d a y})$ \\
\hline Clay silt & $\mathrm{ML}$ & 1 & 2.54 & 0.983 & 2.17 & $1.35 \mathrm{E}-05$ \\
Silty clay & $\mathrm{CH}$ & 2 & 2.54 & 1.020 & 2.33 & $1.37 \mathrm{E}-05$ \\
Soft Clay & $\mathrm{CH}$ & 1 & 2.52 & 0.952 & 2.67 & $1.12 \mathrm{E}-05$ \\
Silty clay & $\mathrm{CH}$ & 14 & 2.52 & 1.070 & 3.00 & $1.15 \mathrm{E}-05$ \\
Clayey silt & $\mathrm{ML}$ & 39 & 2.51 & 0.944 & 3.09 & $1.12 \mathrm{E}-05$ \\
\hline
\end{tabular}

${ }^{*} G_{s}=$ specific gravity; $C_{c}=$ compression indeks; $k=$ coefficient of permeability

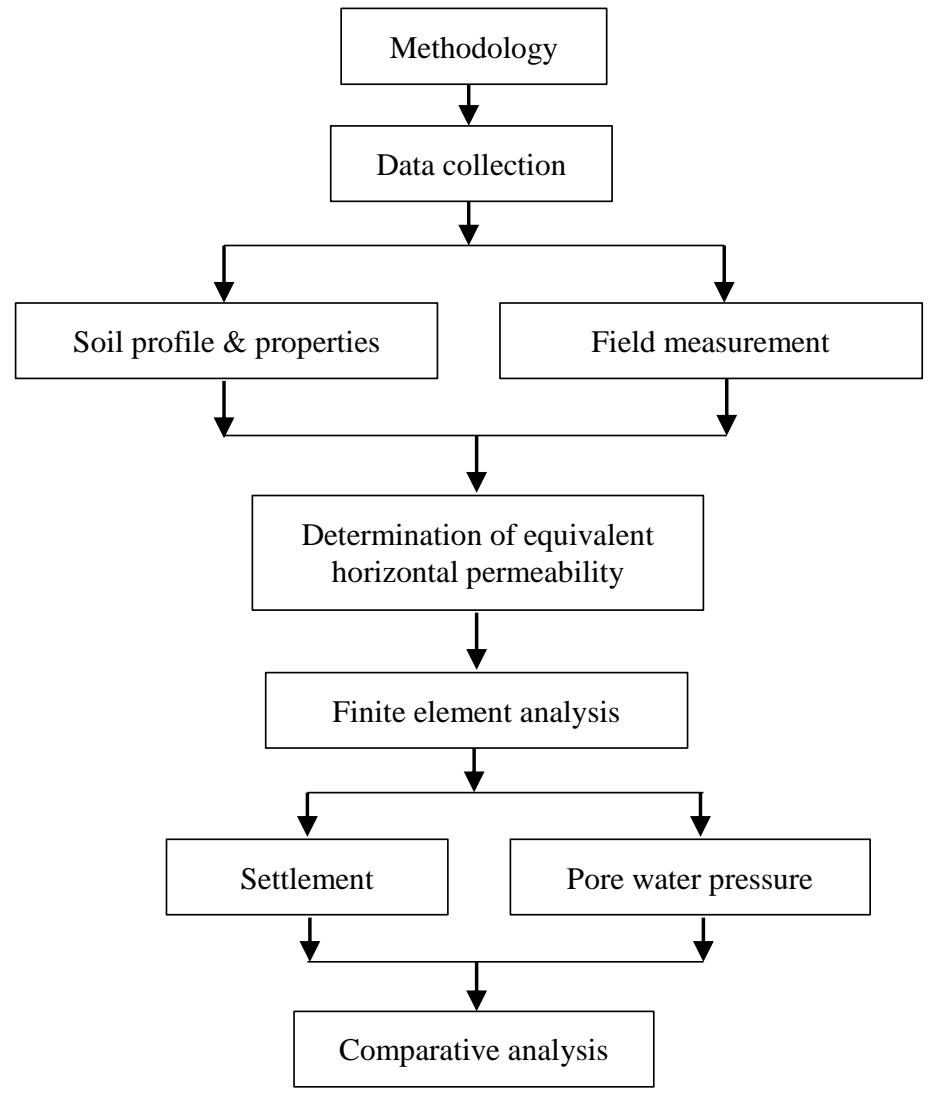

Figure 2. Research methodology flow chart

\section{Numerical Modelling}

The embankment was simulated through Plaxis 2D software that involved settlement and pore water pressure analysis. Referring to reports on the field situation provided by the consultant, the construction of the embankment was divided numerically into five construction steps. The numerical staged modelling for the construction of the embankment was carried out to follow the works at site sequence as follows:

1. Preparation of sand cushion as a drainage layer (14 days)

2. PVDs installation (14 days)

3. Consolidation (28 days)

4. Construction of the road embankment (7 days)

5. Consolidation (177 days)

A medium mesh arrangement and triangular plane-strain model that has 15 nodes was used for the numerical simulation as shown in Figure 3. The number and average size of the elements were about 401 and $2.14 \mathrm{~m}$, respectively. The constitutive models in FEM of fill embankment and sand cushion were modelled as elastic-plastic (MC) while the subground as soft soils (SS). The MC is a relatively easy model and is considered the most widely used model among practising engineers. This model seems to be sufficient for some areas of geotechnical problems is defined by five parameters, i.e. cohesion $(c)$, internal friction angle $(\varphi)$, dilatancy angle $(\psi)$, Poisson's ratio $(v)$, and Young's modulus 
(E). Traditionally, researchers employ the SS model to model the soft ground foundation because of its suitability for primary compression of normally consolidated soils. This model only requires two advanced input parameters, i.e. the modified compression index and modified swelling index. The MC and SS model parameters employed in the numerical analysis are summarised in Table 2.

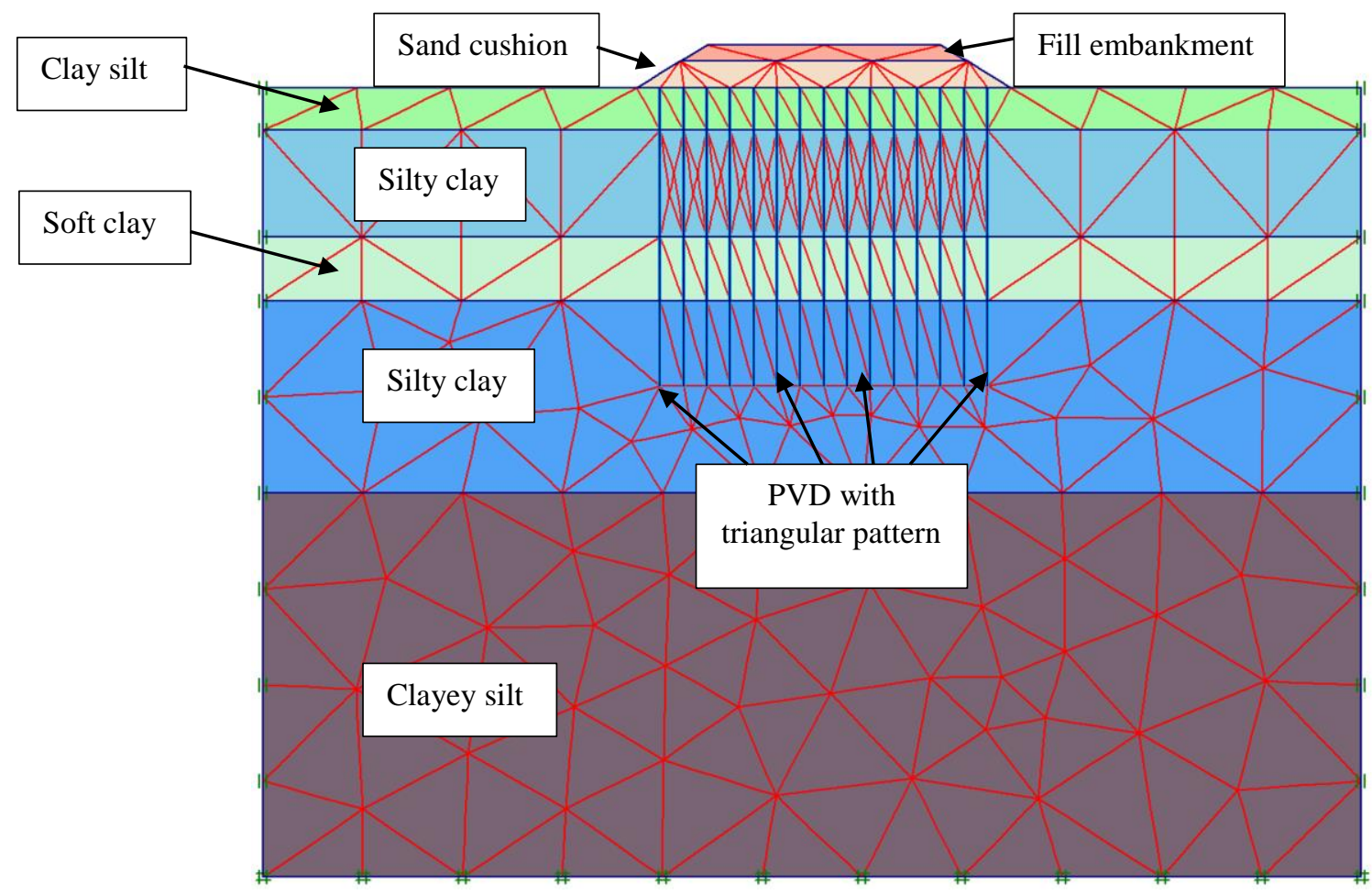

Figure 3. Numerical modelling with medium element distributions

The saturated unit weight $\left(\gamma_{\text {sat }}\right)$, unsaturated unit weight $\left(\gamma_{\text {unsat }}\right)$, cohesion $(c)$, and internal friction angle $(\varphi)$ of soft ground foundation were obtained through a laboratory test. The materials of fill embankment and sand cushion were homogeneous. Besides, the value of materials properties of fill embankment and the sand cushion is based on the typical value from literature. The horizontal and vertical permeability coefficients were obtained from the 1D consolidation test by assuming the soil in Yan as an isotropic soil. The equivalent horizontal permeability $\left(k_{h p l}\right)$ to consider for the effect of smear was calculated by Equations 1 and 2 with the parameters used in Table 2. In addition, the permeability of the fill embankment and sand cushion was assumed to be $1 \mathrm{~m} /$ day. Young's modulus $(E)$ and Poisson's ratio $(v)$ were obtained through $N$ value (SPT) based on AASHTO 2004 with interim 2006 [33].

Table 2. The parameters of equivalent permeability coefficient

\begin{tabular}{lccc}
\hline \multicolumn{1}{c}{ Parameters } & Symbol & Unit & Value \\
\hline The width of the unit cell plane strain & $B$ & $\mathrm{~m}$ & 0.75 \\
The equivalent drainage diameter & $d_{w}$ & $\mathrm{~m}$ & 0.052 \\
Smear zone diameter & $d_{s}$ & $\mathrm{~m}$ & 0.176 \\
Horizontal permeability ratio of undisturbed soil and smear, $\left(k_{h} / k_{s}\right)$ & $k_{r}$ & - & 3 \\
The ratio of the diameter of the smear zone and drainage, $\left(d_{s} / d_{w}\right)$ & $s$ & - & 3.38 \\
Unit cell diameter & $D_{e}$ & $\mathrm{~m}$ & 1.58 \\
The ratio of the diameter of the unit cell and drainage, $\left(D_{e} / d_{w}\right)$ & $n$ & - & 30.3 \\
\hline
\end{tabular}

The PVDs installed in the soft ground was modelled with drains function which considers them as ideal drains as well as high discharge capacity. The drains function sets the line in the geometric model where excessive pore water pressure was fixed to zero in the consolidation analysis. Drains function was activated in the calculation phase instead of the initial conditions to consider the delayed PVDs installation. Traditionally, the PVD application has been simulated by simply fixing the negative pore pressure along the drains boundary [34]. Thus, in this study, the PVDs were modelled by using standard fixities for the horizontal and vertical boundaries. The numerical modelling parameters used in this study are listed in Table 3. 
Hird et al. [11] proposed the equation of geometric matching and permeability of axisymmetry to the plane strain as follows:

$k_{h p l}=\frac{2}{3}\left(\frac{B^{2}}{D_{e}^{2}}\right)\left(\frac{1}{\mu}\right) k_{h}$

Where $k_{h p}$ is the horizontal coefficient of permeability for plane strain, $B$ is the width of a unit cell of plain strain, $D_{e}$ is the equivalent influence zone, $k_{h}$ is the soil's permeability in horizontal, and $\mu$ is the efficiency factor and determined by the following equation:

$\mu=\ln \left(\frac{n}{s}\right)+\left(\frac{k_{h}}{k_{s}}\right) \ln s-0.75$

Where $n=D_{\mathrm{e}} / d_{s}$ and $s=d_{s} / d_{w}$ while $k_{s}$ is the smear zone permeability coefficient. Hansbo [22] proposed the equivalent drain diameter $\left(d_{w}\right)$ is determined by the following equation:

$d_{w}=2(a+b) / \pi$

Where $d_{w}$ is the, $a$ and $b$ are the width and thickness of the PVD, respectively. Hird and Moseley [8] proposed the diameter of smear zone as follows:

$d_{s}=1.6 d_{w}$

Where $d_{s}$ is the diameter of PVD. The equivalent influence zone can be determined based on the drainage distance through the equations proposed by Hansbo [24] as follows:

$D_{e}=1.05 S$

The dimensionless parameters such as $n$ and $s$ were obtained through the calculation of the equations proposed by Hird et al. [11] while $d_{w}$ is calculated by Equation 3. Based on Hird et al. [28], the PVD was installed into the ground with a distance of $1.5 \mathrm{~m}$ between each other, then the plain strain unit width was half of that distance. The parameter specified by Equation 4 with mandrel equivalent diameter for PVD installation in the field was $0.11 \mathrm{~m}$. The diameter of the unit cells was installed with PVD triangle pattern obtained through Equation 5. The value of $k_{h} / k_{s}$ refers to Hird \& Moseley [8] which is proposed for the design of an embankment of 3.0.

Table 3. Numerical modelling parameter

\begin{tabular}{|c|c|c|c|c|c|c|c|c|c|c|c|}
\hline Soil strata (Model-Type) & $\begin{array}{c}\gamma_{\text {unsat }} \\
\left(\mathbf{k N} / \mathbf{m}^{\mathbf{3}}\right)\end{array}$ & $\begin{array}{c}\gamma_{\text {sat }} \\
\left(\mathbf{k N} / \mathbf{m}^{3}\right) \\
\end{array}$ & $\begin{array}{c}k_{h p l} \\
(\mathbf{m} / \mathbf{d a y})\end{array}$ & $\lambda^{*}$ & $\kappa^{*}$ & $\begin{array}{c}c \\
\left(\mathbf{k N} / \mathbf{m}^{2}\right)\end{array}$ & $\begin{array}{c}\phi \\
\left({ }^{\circ}\right) \\
\end{array}$ & $\begin{array}{c}\psi \\
\left({ }^{0}\right) \\
\end{array}$ & $v$ & $\begin{array}{c}E \\
\left(\mathbf{k N} / \mathbf{m}^{2}\right) \\
\end{array}$ & $\begin{array}{c}G \\
\left(\mathbf{k N} / \mathbf{m}^{2}\right) \\
\end{array}$ \\
\hline Fill material (MC-D) & 16.0 & 16.3 & - & - & - & 10 & 30 & 0 & 0.33 & 15 & 6 \\
\hline Sand cushion (MC-D) & 17.0 & 18.5 & - & - & - & 0 & 30 & 5 & 0.33 & 20 & 8 \\
\hline Clay silt (SS-UD) & 14.5 & 15.8 & $2.70 \mathrm{E}-07$ & 0.135 & 0.031 & 10 & 0 & 0 & 0.3 & - & - \\
\hline Silty clay (SS-UD) & 14.0 & 14.4 & $2.74 \mathrm{E}-07$ & 0.133 & 0.031 & 11 & 0 & 0 & 0.4 & - & - \\
\hline Soft clay (SS-UD) & 13.6 & 14.0 & $2.24 \mathrm{E}-07$ & 0.113 & 0.026 & 11 & 0 & 0 & 0.4 & - & - \\
\hline Silty clay (SS-UD) & 13.3 & 13.8 & $2.30 \mathrm{E}-07$ & 0.116 & 0.027 & 10 & 0 & 0 & 0.45 & - & - \\
\hline Clay silt (SS-UD) & 13.1 & 13.6 & $2.24 \mathrm{E}-07$ & 0.100 & 0.023 & 10 & 0 & 0 & 0.35 & - & - \\
\hline
\end{tabular}

$* M C=$ Mohr-Coulomb; $S S=$ Soft Soil; $K^{*}=$ modified swelling index; $\lambda^{*}=$ modified compression index; $c=$ cohesion soil; $\phi=$ internal friction angle; $\psi=$ dilatancy angle; $G=$ shear modulus.

The dimensionless parameters such as $\mathrm{n}$ and $\mathrm{s}$ are obtained through the calculation of the equations proposed by Hird et al. [11] while $d_{w}$ is calculated by Equation 3. Based on Hird et al. [28], the PVD installed into the ground with a distance of $1.5 \mathrm{~m}$ between each other, then the plain strain unit width is half of that distance. The parameter, $d_{s}$ is specified by Equation 4 with mandrel equivalent diameter for PVD installation in the field is $0.11 \mathrm{~m}$. The diameter of the unit cells is installed with PVD triangle pattern obtained through the Equation 5. The value of $k_{r}$ refers to Hird \& Moseley [8] which is proposed for the design of an embankment of 3.0.

\section{Results and Discussion}

Figure 4 shows the results of the analysis in terms of the number of embankment settlements during 177 days of construction. Based on the left side of the embankment (Figure 4a), the settlement calculated through FEM was $6.2 \mathrm{~mm}$ higher than that obtained from field measurements $(4.5 \mathrm{~mm})$. On the right side (Figure $4 \mathrm{~b}$ ), the embankment also shows the same trends as the left side, where the FEM calculation and field measurements were 3.0 and 3.9 mm, respectively. The percentage of settlement differences between field measurements and FEM calculation on the left and right side of the embankment was 38 and 30, respectively. Comparison of Figure 4(a) and (b) highlight good reliability between FEM 
simulation and field measurement which it is proved with apparent from the difference in the total settlement on both sides of the embankment is reasonable. Furthermore, the convergence of the total settlement for both sides of the embankment at the end of the monitoring period also indicates that the equivalent horizontal plane strain permeability applied in this study is very encouraging.
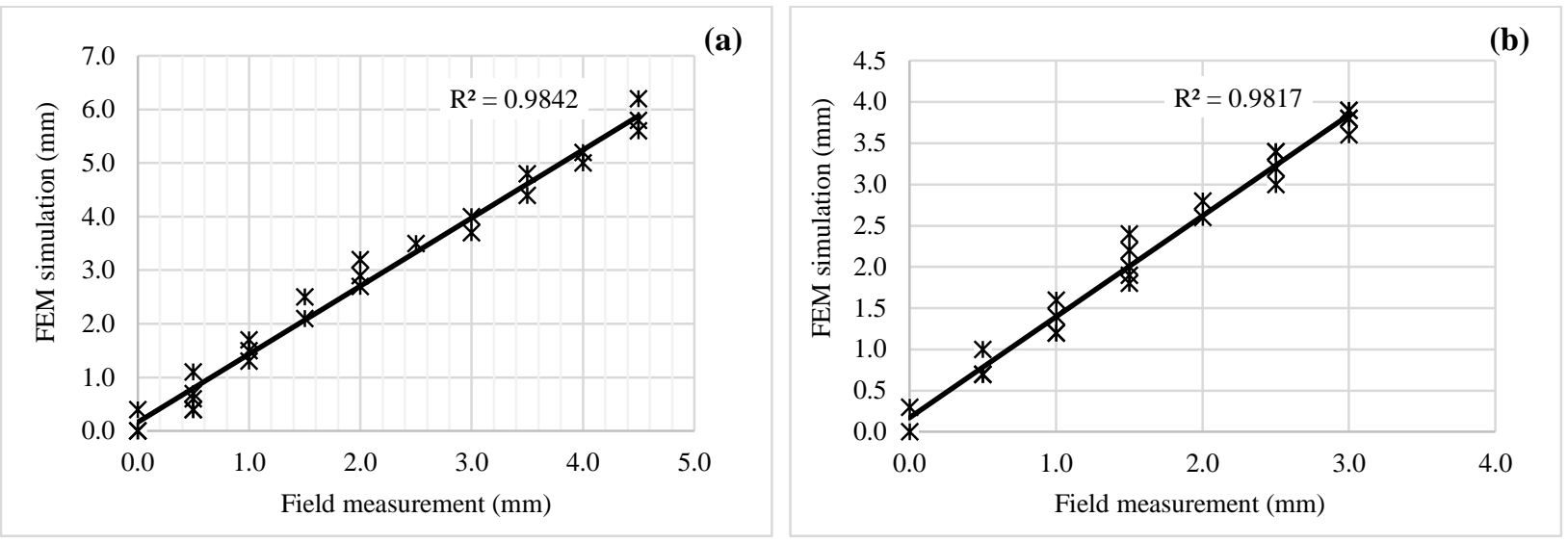

Figure 4. Comparison of settlement between field measurement and FEM calculation (a) left (b) right side of embankment

Figure 5 shows the comparison of the predicted pore pressure values considering the soft soil model and field measurements for the construction (177 days). Pore water pressure on the end field monitoring on the left side of the embankment (Figure 5a), through field measurement $(183 \mathrm{kPa})$ and FEM calculation $(160 \mathrm{kPa})$. This means that the result of calculation through FEM computation is much lower than the field measurement. The right side of the embankment (Figure 5b) also shows the same trend, where the calculation results in the field measurement and FEM was 334 and $389 \mathrm{kPa}$, respectively. Besides, the difference percentage for both sides of the embankment was 13 and 16 . It can be concluded that the difference between the pore water pressure value increases with the distance from the drainage boundary, where Grimstad [35] also supports these findings.
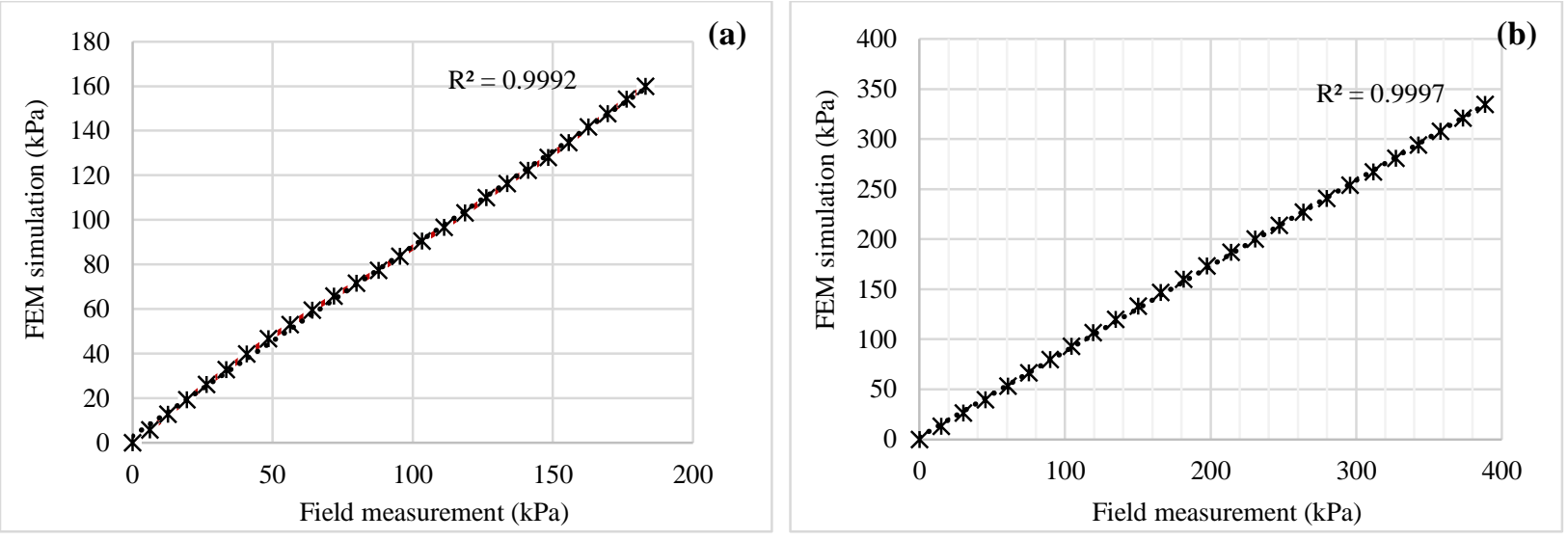

Figure 5. Comparison of pore water pressure obtained through field measurement and FEM calculation (a) left (b) right side of embankment

On the contrary, the total settlement predicted by FEM was higher than that of the field monitoring results. Arulrajah [36] and Huan [37] also found that the total settlement predicted by FEM was slightly lower than that of the field measurements. This difference may be due to the selection of properties that were used for the analysis and the sequence of FEM construction in modelling program.

The coefficient of determination $\left(R^{2}\right)$ plots are shown in Figures 4 and 5 along with the best fit. Generally, the coefficient of determination value for an excellent model is 1 . The total settlement prediction through FEM was almost exactly like the field measurements because the coefficient of determination of both sides of the embankment was 0.9842 and 0.9817 , respectively. In addition, the accuracy of pore water pressure is also acceptable as both parts of the embankment have the coefficient of determination of 0.9992 and 0.9997 , respectively. Obviously, the range of the coefficient of determination values obtained from this study was $0.9817-0.9997$ which shows that the results are accurate and highly correlated. The best value of the coefficient of determination was $99.97 \%$ for pore water pressure at the right side of the embankment while the minimum value of the coefficient of determination was $98.17 \%$ for total settlement 
and also on the right side of the embankment. It seems that the superiority in FEM computational results is due to the adoption of appropriate smear effect parameters. It also indicates the great performance of FEM simulation to estimate settlement and pore water pressure.

As previously mentioned, the smear effect of permeability ratio also contributes to the accuracy of FEM computational prediction. The current study found that the predicted results through the calculation of FEM were almost accurate with those of the field measurements. Therefore, the result of this study can be considered as very good. This finding confirms the relationship between the smear effect of permeability ratio and FEM calculations is an important factor in the performance of predictions. This study produces results that support the findings of previous studies in this field. To produce good results, further studies are needed by diversifying $k_{r}$ and comparing with field measurements

\section{Conclusion}

Based on the published literatures, the FEM analysis has been successful in predicting the behaviour of soft ground improved with PVD. Hence, the main goal of the current study is to determine the performance of the FEM calculation prediction with the smear effect using the smear effect of permeability ratio of 3 . This study found that the percentage difference in FEM results and measurements in the field ranges from 13 to 38. Also, the comparison between FEM computational and field measurements in terms of the coefficient of determination indicates that FEM is capable to predict appropriate yields for settlement and pore water pressure values. The results of this study also confirm that settlement and pore water pressure predicted by FEM analysis show reasonable agreement with field measurements using the equivalent permeability proposed by Hird [11]. Evidence from this study can be used as a reference to other researchers to further expand this research. In addition, this study contributes to our knowledge in giving an overview of FEM's calculation performance. Finally, there are important limitations to consider the parameters ds/dw can be considered as the contributors to the accuracy of the prediction. Therefore, further research is needed to determine whether this parameter can produce an accurate prediction. Furthermore, further investigations by varying the value of the zone diameter of the smear and the smear effect of permeability ratio to explore and investigate the results through the calculation of FEM.

\section{Funding and Acknowledgements}

The authors wish to thank the Centre for Engineering Education Research (PeKA), Smart and Sustainable Township Research Centre (SUTRA), Faculty of Engineering and Built Environment (FKAB), Universiti Kebangsaan Malaysia (UKM) for providing the facility for this research work. Besides, the appreciation also to the Ministry of Education (MOE), Malaysia for providing scholarships for the project. Also, gratefully acknowledge to the Politeknik Ungku Omar (PUO) for providing the opportunity to carry out this project.

\section{Conflicts of Interest}

The authors declare no conflict of interest.

\section{References}

[1] R. Che Mamat, Engineering properties of Batu Pahat soft clay stabilized with lime, cement and bentonite for subgrade in road construction, MS Thesis, Faculty of Civil and Environmental Engineering, Universiti Tun Hussien Onn Malaysia, 2013.

[2] Bunawan, Aliff Ridzuan, Ehsan Momeni, Danial Jahed Armaghani, Khairun Nissa binti Mat Said, and Ahmad Safuan A. Rashid. "Experimental and Intelligent Techniques to Estimate Bearing Capacity of Cohesive Soft Soils Reinforced with Soil-Cement Columns.” Measurement 124 (August 2018): 529-538. doi:10.1016/j.measurement.2018.04.057.

[3] Yildiz, Abdulazim. "Numerical Analyses of Embankments on PVD Improved Soft Clays." Advances in Engineering Software 40, no. 10 (October 2009): 1047-1055. doi:10.1016/j.advengsoft.2009.03.011.

[4] Adnan Hasan, Hanan. "Prediction the Behavior of Piles in Clayey Soils." International Journal of Engineering \& Technology 7, no. 4.20 (November 28, 2018): 157. doi:10.14419/ijet.v7i4.20.25918.

[5] Indraratna, Buddhima, I. Sathananthan, C. Bamunawita, and A.S. Balasubramaniam. "Theoretical and Numerical Perspectives and Field Observations for the Design and Performance Evaluation of Embankments Constructed on Soft Marine Clay." Ground Improvement Case Histories (2015): 83-122. doi:10.1016/b978-0-08-100192-9.00003-x.

[6] Rowe, R. Kerry, and C. Taechakumthorn. "Combined Effect of PVDs and Reinforcement on Embankments over Rate-Sensitive Soils.” Geotextiles and Geomembranes 26, no. 3 (June 2008): 239-249. doi:10.1016/j.geotexmem.2007.10.001.

[7] Chai, Jin-Chun, Jack Shui-Long Shen, Martin D. Liu, and Da-Jun Yuan. "Predicting the Performance of Embankments on PVDImproved Subsoils.” Computers and Geotechnics 93 (January 2018): 222-231. doi:10.1016/j.compgeo.2017.05.018.

[8] Hird, C. C., and V. J. Moseley. "Model Study of Seepage in Smear Zones around Vertical Drains in Layered Soil." Géotechnique 50, no. 1 (February 2000): 89-97. doi:10.1680/geot.2000.50.1.89. 
[9] Saowapakpiboon, J., D.T. Bergado, P. Voottipruex, L.G. Lam, and K. Nakakuma. "PVD Improvement Combined with Surcharge and Vacuum Preloading Including Simulations." Geotextiles and Geomembranes 29, no. 1 (February 2011): 74-82. doi:10.1016/j.geotexmem.2010.06.008.

[10] Jang, W. Y. "Behaviors of Embankment on PVD-Improved Haiphong Clay.” Soil Mechanics and Foundation Engineering 55, no. 2 (May 2018): 120-126. doi:10.1007/s11204-018-9513-5.

[11] Hird, C.C., I.C. Pyrah, D. Russell, and F. Cinicioglu. "Modelling the Effect of Vertical Drains in Two-Dimensional Finite Element Analyses of Embankments on Soft Ground." Canadian Geotechnical Journal 32, no. 5 (October 1995): $795-807$. doi:10.1139/t95-077.

[12] W. Kjellman, Accelerating consolidation of fine grained soils by means of cardboard wicks, in: 2nd Int. Conf. Soil Mech. Found. Eng., Rotterdam, 1948: pp. 302-305.

[13] Yan, S. W., and J. Chu. "Soil Improvement for a Road Using the Vacuum Preloading Method." Proceedings of the Institution of Civil Engineers - Ground Improvement 7, no. 4 (October 2003): 165-172. doi:10.1680/grim.2003.7.4.165.

[14] Tang, M., and J. Q. Shang. "Vacuum Preloading Consolidation of Yaoqiang Airport Runway." Ground and Soil Improvement (January 2004): 9-19. doi:10.1680/gasi.31708.0002.

[15] Stark, Timothy D., Perry J. Ricciardi, and Ryan D. Sisk. "Case Study: Vertical Drain and Stability Analyses for a Compacted Embankment on Soft Soils.” Journal of Geotechnical and Geoenvironmental Engineering 144, no. 2 (February 2018 ): 05017007. doi:10.1061/(asce)gt.1943-5606.0001786.

[16] Chai, Jinchun, Norihiko Miura, Saiichi Sakajo, and Dennes Bergado. "Behavior of Vertical Drain Improved Subsoil Under Embankment Loading.” Soils and Foundations 35, no. 4 (1995): 49-61. doi:10.3208/sandf.35.4_49.

[17] Rujikiatkamjorn, Cholachat, and Buddhima Indraratna. "Environmental Sustainability of Soft Soil Improvement via Vacuum and Surcharge Preloading." Geo-Congress 2014 Technical Papers (February 24, 2014): 3658-3665. doi:10.1061/9780784413272.354.

[18] R.A. Barron, Consolidation of fine-grained soils by drain wells, Trans. ASCE. 113 (1948) 718-724.

[19] Chai, Jun-Chun, and Norihiko Miura. "Investigation of factors affecting vertical drain behavior." Journal of Geotechnical and Geoenvironmental Engineering 125, no. 3 (1999): 216-226. doi:10.1061/(ASCE)1090-0241(1999)125:3(216).

[20] Sharma, J S, and D Xiao. "Characterization of a Smear Zone Around Vertical Drains by Large-Scale Laboratory Tests." Canadian Geotechnical Journal 37, no. 6 (December 2000): 1265-1271. doi:10.1139/t00-050.

[21] Tanchaisawat, T, D Bergado, and P Voottipruex. "Numerical Simulation and Sensitivity Analyses of Full-Scale Test Embankment with Reinforced Lightweight Geomaterials on Soft Bangkok Clay." Geotextiles and Geomembranes 26, no. 6 (December 2008): 498-511. doi:10.1016/j.geotexmem.2008.05.005.

[22] Hansbo, Sven. "Consolidation of clay by bandshaped prefabricated drains." Ground Engineering 12, no. 5 (1979).

[23] Hansbo, S. “Aspects of Vertical Drain Design: Darcian or Non-Darcian Flow.” Géotechnique 47, no. 5 (October 1997): 983992. doi:10.1680/geot.1997.47.5.983.

[24] Hansbo, S. "Consolidation of fine-grained soils by prefabricated drains." In Proceedings of the 10th international conference on soil mechanics and foundation engineering, Stockholm, vol. 3, pp. 677-682. AA Balkema Rotterdam, The Netherlands, 1981.

[25] J.J. Rixner, S.R. Kraemer, A.D. Smith, Prefabricated vertical drains, Washington, DC, US., 1986.

[26] Onoue, Atsuo, Nai-Hsin Ting, John T. Germaine, and Robert V. Whitman. "Permeability of disturbed zone around vertical drains." In Geotechnical Engineering Congress-1991, pp. 879-890. ASCE, 1991.

[27] Almeida, M. S. S., and C. A. M. Ferreira. "Field, in situ and laboratory consolidation parameters of a very." In Predictive Soil Mechanics: Proceedings of the Wroth Memorial Symposium Held at St. Catherine's College, Oxford, 27-29 July 1992 , p. 73. Thomas Telford, 1993.

[28] Hird, C. C., I. C. Pyrah, and D. Russel. "Finite Element Modelling of Vertical Drains Beneath Embankments on Soft Ground." Géotechnique 42, no. 3 (September 1992): 499-511. doi:10.1680/geot.1992.42.3.499.

[29] Indraratna, Buddhima, and I. W. Redana. "Plane-strain modeling of smear effects associated with vertical drains." Journal of Geotechnical and Geoenvironmental Engineering 123, no. 5 (1997): 474-478. doi:10.1061/(ASCE)1090-0241(1997)123:5(474).

[30] C. Rujikiatkamjorn, B. Indraratna, M.D. Wirya Ardana, Smear zone characterization associated with vertical drain installation, in: Southeast Asia Conf. Soft Soils Eng. Gr. Improv. Soft Soils, Southeast Asian Geotechnical Society, Bandung, West Java, Indonesia, 2014: pp. F1-1-F1-8.

[31] D.T. Bergado, H. Asakami, M.C. Alfaro, A.S. Balasubramaniam, Smear effects of vertical drains on soft Bangkok clay, J. Geotech. Eng. 117 (1991) 1509-1530. doi:10.1061/(ASCE)0733-9410(1991)117:10(1509). 
[32] Nguyen, Thanh Trung, Buddhima Indraratna, and Cholachat Rujikiatkamjorn. "A Numerical Approach to Modelling Biodegradable Vertical Drains.” Environmental Geotechnics (August 10, 2018): 1-9. doi:10.1680/jenge.18.00015.

[33] N.C. Samtani, E.A. Nowatzki, Soils and Foundations - FHWA-NHI-06-088, Washington, D.C., 2006.

[34] Indraratna, Buddhima, Chamari Bamunawita, and Hadi Khabbaz. "Numerical Modeling of Vacuum Preloading and Field Applications.” Canadian Geotechnical Journal 41, no. 6 (December 2004): 1098-1110. doi:10.1139/t04-054.

[35] G. Grimstad, M.A. Haji Ashrafi, S.A. Degago, A. Emdal, S. Nordal, Discussion of 'Soil creep effects on ground lateral deformation and pore water pressure under embankments,' Geomech. Geoengin. 11 (2016) 86-93. doi:10.1080/17486025.2014.985338.

[36] Arulrajah, A., H. Nikraz, and M. W. Bo. "Finite Element Modelling of Marine Clay Deformation Under Reclamation Fills." Proceedings of the Institution of Civil Engineers - Ground Improvement 9, no. 3 (July 2005): 105-118. doi:10.1680/grim.2005.9.3.105.

[37] Huan, Teh Zhi, Rini Asnida Abdullah, Mohd For Mohd Amin, Mohd Azril Hezmi, Ahmad Safuan A Rashid, and Mohd Nur Asmawisham Alel. "Performance Prediction of Prefabricated Vertical Drain in Soft Soil Using Finite Element Method." Jurnal Teknologi 76, no. 2 (September 8, 2015). doi:10.11113/jt.v76.5435. 